\title{
The Effect of Corporate Governance on Corporate Performance of General Insurance Companies in Kenya
}

\author{
Chrispine Otieno Osedo ${ }^{1}$, Joseph Mwanza ${ }^{2 *}$, Dr. Joan Lilian Ogendo, $\mathrm{PhD}^{2}$
}

${ }^{1}$ Student, School of Business The Catholic University Of Eastern Africa, Kenya

${ }^{2}$ Lecturer, School of Business The Catholic University Of Eastern Africa, Kenya

DOI: $10.36347 /$ sjebm.2020.v07i09.007

| Received: 06.09.2020 | Accepted: 14.09.2020 | Published: 25.09.2020

*Corresponding author: Joseph Mwanza

\section{Abstract}

Original Research Article

The study established the effect of corporate governance on corporate performance of general insurance companies in Kenya. The specific objectives invloved to determine the effect of Board size, the effect of the CEO quality, the effect ownership concentration and the effect of audit committee independence on corporate performance of general insurance companies in Kenya. Primary and secondary data of the study was used. A semi-structured questionnaire was used to collect the primary data. The secondary data was obtained from the financial statements of the given general insurance companies. A census sample of 22 companies was done since it is a small population. The study used regression analysis technique to establish the specific objectives. The findings of the study reveals that board size, CEO duality, ownership concentation have no significant effect on corporate performance. Overall, corporate governance has a very weak correlation with corporate performance. However, board size has moderately strong correlation with corporate performance. CEO duality and audit committee have moderately weak correlation with corporate performance. Ownership concentration has weak correlation with corporate performance. Theoretically, this study contributes to the advancement of agency theory and stakeholders theory. Policies on corporate governance may be useful in specified organizations to make certain effective and efficient corporate performance. The study identifies the normal practice of the general insurance organizations through its findings.

Keywords: Corporate Governance, Board Size, Audit Committee Independence, CEO Duality, Ownership Concentration, Corporate Performance.

Copyright @ 2020: This is an open-access article distributed under the terms of the Creative Commons Attribution license which permits unrestricted use, distribution, and reproduction in any medium for non-commercial use (NonCommercial, or CC-BY-NC) provided the original author and source are credited.

\section{INTRODUCTION}

Every internal mechanism is subject to managerial influence that tends to describe compliance to external mechanisms, such as guidelines by regulatory authorities. Corporate governance is the practice used through structures to express and administer business dealings of an organization to realize enhanced corporate accounting and the overall success. Palanissamy [1] posits that the board does not necessarily have to follow a given conventional structure, but in most instances stakeholders and shareholders tend to prefer one that supports clear division of roles to promote transparency and independence. Kyereboah-Coleman \& Biekpe [2] argue that their exist a significant connection between an entrenched culture of governance and performance of organizations. The way a firm is governed is expected to influence the organization's performance.

Contextually, Kenya represents one of Africa's most industrial and highly synchronized insurance markets, with dreadful historic growth and yet superior near term scenario. The industry boasts of 45 players out of which 22 offer general or short-term, 9 life or long term and 14 composite insurance [3]. The life segment has the strongest growth potential yet like in other African economies, the Kenyan industry is currently dominated by the non-life component. This study will cover the 22 general insurance firms.

Measuring corporate worth can be completed by analyzing the growth of share price in secondary market, if there is a boost in share price that means that there is increased corporate value, because the corporate value essentially is the value of share market added by the value of requirement market or long term debts. Increased share value shows better public trust on the company, so that they can pay higher, this is based on their anticipation to also attain high return [4].

Generally, extant literature shows that growth in profit of companies is positively and significantly associated with return on equity, net profit margin, debt 
to equity ratio, current ratio, and return on assets. In fact, Heikal, Khaddafi, \& Ummah [5] link earnings growth to return on assets by affirming that these two constructs are significantly related and they exhibit a positive linkage. Net profit margin and ROE are closely linked with income growth because of the significant relationship that underpins this connection. However, earnings growth has a negative, but significant effect with current ratio and debt to equity ratio. Rosika, Prananingrum, Muthalib, Azis, \& Rohansyah [4] confirmed that firm value is not significantly affected by ROE, while at the same time the former depicts a significantly positive connection with ROA. Equally, earnings per share is negative and is not significantly associated with firm value. Therefore, ROE, ROA, and earnings pershare have concurrent significant effect on firm value.

A lucrative company yielding a stable revenue stream with self-effacing capital expenditure has the capability to mix shareholder wealth at an attractive rate over time. Das [6] suggest that estimating a company's sustainable profitability is a big defy to investors. Companies have not been able to increase revenue and return on capital employed simultaneously as they are not also compatible in comparison with the global capital markets. The level that corporate performance is attributable to good internal corporate governance mechanisms is inconclusive. Lack of empirical research makes it difficult for strategic management to design governance contracts to address the agency problem [7].

Board committee's activities need to provide benefits of specialization, efficiency, accountability and costs such as information segregation [2]. Most organization expect the CEO's independence in monitoring of managerial actions to be easier. It is assumed that independent audit committees that are diverse and possess financial competence, often hold quality meetings to enhance the quality of their financial reporting [8]. However, ownership structure is ascertained to protect the shareholders' interests in various organizations [9].

Given the importance of general insurance to the stability of businesses in Kenya, it is critical to establish the efficacy of internal corporate governance practices in dealing with the agency problem [10]. The Objectives of the Study were:

i. The effect of board size on corporate performance of the general insurance firms in Kenya.

ii. The effect of CEO duality on corporate performance of the general insurance firms in Kenya.

iii. The effect of ownership concentration on corporate performance of the general insurance firms in Kenya. iv. The effect of audit committee independence on corporate performance of the general insurance firms in Kenya.

Theoretically, this research work adds to the development of the agency theory as well as stakeholder theory in light of the predictor and outcome variables of the study. The study relates to the key expositions of the theories of corporate performance and corporate governance, and provides pertinent contribution to these theories. Policies on corporate governance may be useful in specified organizations to make certain effective and efficient corporate performance. The given policies may provide opportunities for corporations to have a stronger business position in the market than their rivals in the insurance industry. The study will identify the normal practice of these insurance organizations and confirm its findings. The findings from this study may also serve as an important point of reference for students, academicians, and researchers within the field of corporate performance, corporate governance, or both as elucidated herein.

The study covered an investigation of the effect of corporate governance on performance of general insurance companies. The Kenyan insurance industry comprises of 45 firms out of which 22 offer general or short-term, 9 life or long term and 14 composite insurance [3]. The study considers all the 22 insurance firms that offer general insurance.

\section{LITERATURE REVIEW \\ Board Size and Firm Performance}

Kyereboah-Coleman and Biekpe [2] argue that there is no gain saying since the structure of governance of an organization significantly relates to the receptive capability of factors external to it, which interfere with how it performs. Though corporate governance is multidimensional, Ghanaian corporations tend to utilize structures of the board that are two-tier and they often keep board sizes that are relatively smaller to enhance the way they perform. Independent directors who are external to the firm help to create new ways of managing a company to promote its competitiveness and corporate entrepreneurship. The board size exhibits a positive association to ROA ans Tobin's q.

For the Ghanaian case, organizational performance and the board's composition are negatively related. Role separation, particulary amongt a board's char and the chief executive officer has been shown to lessen tensions among members of the board and the managers, and as such, contributing greatly to organizational performance. Evidence from scholarly literature demonstrates that improved and superior performance of firms is made possible by an asset portofolio that comprises of greater fixed assets. Moreover, the performance of those firms that choose equity financing is less than those that use debt 
financing. Size is one of the fundamental characteristics of a firm that directly affects the way an organization performs relative to the rivals in the marketplace [2]. Akpan and Amran [11] established a positively significant connection between performance of an organization and its board education and board size. Conversely, board age, independence of a board, and board equity are not significantly related. Performance of a corporation has not been negatively but significantly linked to the board women.

Palanissamy [1] argues that the ever-dynamic nature of corporate governance has led to fundamental questions being raised as to whether a firm's CEO should double as the board's chairperson. There is every reason for firms to relook at their structures and device new approaches in light of the modern-day pressure mounted to their boards by shareholders and the enforcement agencies. Notwithstanding evidence suggesting that there is no direct link among organizational performance, separation or duality, a healthy organizational corporate governance is supported by a separation model since it enhances the much-needed balance. Ning, Davidson, and Wang [12] explain that directors are more likely to encounter internal conflicts because agency problems are bound to occur in circumstances where the size of the board increases. These inconclusive findings make it difficult to generalize the connection between the board's size and how general business insurance companies perform in the market.

\section{CEO Duality and Firm Performance}

Agency theory continues to be used to a great extent to explain the concept of CEO duality. Some studies have established that performance and CEO duality are not significantly related. In fact, existing scholarly enquiry points out that the relationship is negative. Even though CEO duality was initiated in USA, auditing, accounting and corporate governance scandals like Parmalat, Worldcom, and Enron, among others experienced in 2000s have shocked many countries [8]. One of the vital reasons of these scandals is the confusion of independent auditing and internal auditing, as well as the misleading approach in decision-making by managers.

There are no unfavourable shortcomings associated with the chief executrive officer of an organization occupying two positions since this state of affairs comes with higher remuneration of the CEO coupled with the sole utilization of the reporting of financial data by whoever is holding the position for the management of the earnings. Ghosh \& Moon [13] argue that a primary issue that has been documented by many management scholars allude that most of the CEOs occupying the position of the chair may exercise their powers to seek rent. Nonetheless, there exist certain circumstances where occupation of dual roles in a firm is beneficial, particularly under a functional contracting theory. Based on the postulations of the contracting theory, the riskiness of a corporation increases substantially when one specific person acts as the chair while at once being the CEO. In this regard, the person at the helm of an organizations fails to create a progressive trajectory of a specific area of experience, including managerial expertise. Accordingly, heads of companies holding two positions have limited capacity to create essential and meaningful business strategies in the market for the reason that they either pay less dividends or cannot underscore the growth of a business through recurrent acquisitions.

Large firms are progressively adopting a different and autonomous person to be the chairperson of the board. However, this practice has also yielded considerable challenges in management of organizations, such the infamous public disagreement between the board's chairperson and the group CEO of AIG insurance corporation (Krause, Semadeni, \& Cannella, 2014). The conflict eventually came to an end after the resignation of the board chairman, a situation that led to the questioning of the trustworthiness of the CEO non-duality. Literature on duality demonstrates that spliting of the position of chairperson of the board from that of the CEO is not by itself a prerequisite of attaining organizational performance. Performance of organizations is significantly contingent upon the tenure of the CEO.

\section{Ownership Concentration and Firm Performance}

Kalezic [9] suggests that for firms operating under poor instruments of corporate governance and/or inappropriately created capital markets, the linkage between a company's performance and ownership concentration could vary as either negative or positive after controlling for endogeneity. The impact is positive in instances where investors outside the firm are able to leverage high concentration as a technique of promoting their interests and needs in a professional manner. In effect, a poor system of corporate governance in Montenegro is addressed through high ownership concentration. A negative impact exists in circumstances where a firm has both minority and largest shareholders where the latter group aspires to follow a self-centred interests at the expense of the former. In fact, a negative association btween performance of companies and ownership concentration becomes more pronounced when the majority shareholder has a managerial position in a corporation and exhibits an entrenchment behaviour. The current values of Return on Equity are determined by values from previous Return on Equity.

Vintila \& Gherghina [14] explored the nexus between the valued attached to a firm and its ownership. Tobin's Q ratio acted as a proxy in the measurement of firm value. The study considered the first three shareholders who were deemed to be the largest, including the shareholders considered to possess the 
two largest holdings as well as the totality of the shareholders who were the first three largest. They identified a negative influence in the ownership of the third leading shareholder, concerning the progression of directors monitoring, hence following their individual goal achievements.

The study outcomes established that the company value was positively influenced by the combination of the shareholders who were within the spectrum of the three largest group, and this finding supports the viewpoints espoused by the concept of ownership concentration. The connection between company value and the entirety of the shareholders grouped as possessing the two largest holdings was not recognized as statistically significant.

Theory-based knowledge suggests that structures characterized with high ownership concentration are bound to foster private benefits as opposed to lowly concentrated ownerships that have agency costs. Kalezic [9] asserts that the principalprincipal problems are morely likey to occur in the future in high ownership concentration despite being initially lessened to promote performance. Furthermore, a firm that has a controlling owner in place possesses a higher probability of capitalizing on performance. Ma \& Naughton [15] argued that highly concentrated ownerships enhance better performance of firms than any alternative form of ownership. Evidence from the study suggested that total ownership concentration was not statistically significant with performance of firms, while tradable ownership concentration had a strong and positive effect. A combination of tradable and total ownership concentrations was associated with the highest level of firm performance.

Daoud, Al-Sraheen, and A leqab [16] argue that corporate boards are ineffective in their monitoring roles in situations where the efficiency of the board has been weakened because of family concentrated ownership and the joint execution of duties as a CEO and a board's chairperson. Shieding of stakeholders' interests given that they are minority in a firm is a fundamental exercise that ought to be carried out by regulations and other mechanisms instituted at the firm level. Simply put, firm-level mechanisms can supplement regulations to guard the wellbeing of minority shareholders. Firms separating leadership between board chairperson and a CEO may obtain higher board effectiveness, while firms with concentrated family ownership may limit the monitoring function of board. This can, in turn, lead to weakness in board effectiveness, particularly in ensuring that a company's financial reporting is adequately monitored.

Permwanichagun, Kaenmanee, Naipinit, and $\mathrm{Na}$ Sakolnakorn [17] note that e-commerce industry comprises of females who majorly are in sole proprietorship and they are degree holders. It is worth noting that these cadre of women spend a considerable amount of time in their businesses premises and they are involved in making deliveries of different product offerings that they trade. Possession of relevant entrepreneurial knowledge coupled with the intial investments costs are examples of the tribulations encountered by sole proprietorships, e-commerce entrepreneuers, and e-commerce entreprenuers.

\section{Audit Committee independence and Corporate Performance}

Supporting analysis demonstrates that development of governance mechanisms hinges on the recurrent meetings of the audit committee as well as its independence. Obviously, this creates opportunities for the board to be presented with actual financial data as all loopholes that make it possible to enter misleading and erroneous figures are dealt with. In effect, a firm gains tremendously from an independent audit committee that holds its meeting regularly because any fraudulent activity or misrepresentation of the actual position of a corporation comes to the core in time. Regulators that gradually support enhanced independence of the committee and the board are suggested [18].

Performance possesses an outstanding link with independent and active audit committees. Performance of firms has not been associated with either the financial expertise or audit committee's size because all these variables lack a significant relationship among them. Mandatory regulatory requirements that need to be regarded as critical for performance of corporations involve components of the audit committee that reduce agency costs, financial expertise desirable in the team, the number appropriate for the company audit committee, including its independence [19].

Zraiq \& Bt Fatzil [20] argue that ROA and the size of the audit committee do not depiect any significant linkage despite them having a positive relationship. However, there exist a positively significant association between earnings per share and audit committee's size. ROA and meetings of the audit committee reveal a positively significant linkage.

ICPAK [21] confirms that a good number of entities cannot determine the minimum qualifications desired unless explicitly affirmed in the statutes that they use because of the way they undertake selections for the board. It is essential that the executive management of a firm is not present during meetings since it is desirable to have a separate summit between external and internal auditors and the audi committee, at least once a year. There are no successions planning necessities specified, since the term for the entire composition of the board come ends at a similar period. Related to capability and skills, there is lack of suitable 
competencies and skill sets within the board coupled with absence of opportunities for training to improve on skills. The other formidable shortcomings include committee independence because of politics, quorum challenges, lack of succession planning, and financing.

\section{Knowledge Gaps}

This study was motivated by both conceptual and contextual knowledge gaps. Conceptually, Akpan \& Amran [11] focused on board characteristics and company performance. Bansal \& Sharma [18] focused on performance of firms by considering corporate governance and audit committee. Dogan, Elitas, Agca, \& Ogel [8] focused on firm performance by considering CEO duality. Kalezic [9] focused on firm performance by taking into perspective ownership concentration as the independent variable. Kyereboah-Coleman \& Biekpe [2] focused on firm performamce as the outcome variable while using CEO duality, board composition, board size as constructs of explanatory variable. ICPAK [21] and Mwangi [22] deleved into audit committee and performance. To fill these empirical and contextual gaps, the study proposes to test the effects of all the dimensions of corporate governance against all the identified measures of the outcome variable. Outside the African region, Bansal \& Sharma [18] delved into subconstructs of performance and corporate governance in India, Daoud, Al-Sraheen, \& A Leqab [16] in Jordan, Dogan, Elitas, Agca, \& Ogel [8] in Turkey and Kalezic [9] in Montenegro. In the African region, Akhtar [23] study on corporate governance sub constructs were conducted in Nigeria, Kyereboah-Coleman \& Biekpe [2] in Ghana; and ICPAK [21] and Mwangi [22] in Kenya. In Kenya, ICPAK [21] and Mwangi (2018) conducted research in the Public Sector. However, the contextual gap is conducting research in the general insurance companies within the Kenyan context.

\section{RESEARCH METHODS}

This study employed a cross sectional research survey. The cross-sectional research made observations at only one period in time. This cross-sectional research analogously took one still picture of those companies providing general insurance covers in Kenya. The applicability of this type of design meant that collection of data from the participants took place at a given specified time. General insurance companies in Kenya constitute the population from which data was collected.

The insurance industry in Kenya comprises of 45 firms out of which 22 offer general or short-term, 9 life or long term and 14 composite insurance [10]. The population considered in this study consisted of all the 22 insurance firms that offer general insurance. The unit of analysis was the insurance organizations. The targeted respondents were the top management staff, which comprise of chief executive officers (CEOs) of insurance firms or any manager such as the general managers and the financial managers who are knowledgeable about the organization and can be able to respond to issues concerning how corporations perform from the perspective of corporate governance.

The researchers made use of questionnaires, and in particular, semi-structured ones, as the key research instrument. For data collection to be successful, research instruments are utilized to achieve this process since they encompass critical evidential approaches of obtaining information around a phenomenon. Basically, the researcher ensured that the questionnaire selected met the set criteria for reliability and validity. The suitability of the questionnaire largely determines how valid or reliable a study will be. Questionnaire and interview guides are data collection instrument mostly used on normative surveys [24]. Sets of questions were purposely formulated to collect perceptions, views, and opinions of a study's respondents in the form of information or data. Interviews were also used in order to engage face-toface with persons of interest to cooperate and come up with viewpoints in a discussion that borders on common concern.

The researchers sampled insurance firms dealing in general insurance in Kenya form the sampling frame of the study and a Census survey formed the main technique of collecting data from all the 22 insurance companies offering general insurance as recommended by Cooper and Schindler [25], since the population is a small number. Utilization of census is important in research since it incorporates all members of a study population, provides opportunities for the identification of negative feedback, and increases the confidence interval [25].

The study obtained both secondary and primary data from the sampling frame for subsequent analysis. Administration of questionnaires to respective insurance organizations yielded data, which was later analyzed in the form of inferential and descriptive statistics. Drop and pick method technique of administering questionnaires was used to aid filling of questionnaires by respondents who were preoccupied by organizational responsibilities or activities. The method ensured that the questionnaire return rate was relatively higher as it allowed respondents to fill this data collection instrument at their convenient time. Further, courtesy calls and follow-up visits were made by the researcher with the objective of ensuring that respondents were reminded of the need to have the research questionnaires filled.

Secondary data on corporate performance was derived from both the Insurance Regulatory Authority's annual reports and financial statements for the period 2015-2019 of the insurance firms. Other relevant secondary data not found in the annual reports were 
also downloaded from the Insurance Regulatory Authorities website.

Statistical Package for Social Science (SPSS) as a statistical software was used in aiding the analysis of data collected. content analysis and retroactive research designs attempts to explore causes and effect relationships where causes already uses what already exists and looks backwards to explain why. Determination of the effect of the predictor variable on the dependent variable was undertaken through regression analysis. Regression model was developed as presented below:

$$
Y=\beta_{0}+\beta_{1} X_{1}+\beta_{2} X_{2}+\beta_{3} X_{3}+\beta_{4} X_{4}+\varepsilon
$$

Where,

$$
\begin{aligned}
& \mathrm{Y}=\text { Corporate performance as measured by } \\
& \text { corporate governance } \\
& \mathrm{X}_{1} \text { is Board Size, }
\end{aligned}
$$

$\mathrm{X}_{2}$ is CEO Duality
$\mathrm{X}_{3}$ is Ownership concentration,

$\mathrm{X}_{4}$ is Audit committee independence

$\beta_{1}, \beta 2, \beta 3, \beta 4=$ coefficients

$\beta_{0}=$ Constant

$\varepsilon=$ regression error term.

\section{RESULTS AND DISCUSSION Response Rate}

The researcher requested the insurance companies to identify themselves by rubber-stamping on the response questionnaire. This was done by almost all of the respondents of the study. The study identified 22 general insurance companies. This response rate represented $100 \%$ of the respondents.

\section{Demographic Data}

The demographic data involves the gender, age

\begin{tabular}{|c|c|c|c|}
\hline \multirow{2}{*}{\multicolumn{2}{|c|}{ ate }} & \multirow{5}{*}{$\begin{array}{l}\text { Frequency } \\
16 \\
5 \\
1\end{array}$} & \multirow{5}{*}{$\begin{array}{l}\text { Percent } \\
73 \\
23 \\
4\end{array}$} \\
\hline & & & \\
\hline Gender & Male & & \\
\hline & Female & & \\
\hline & Not Specified & & \\
\hline \multirow[t]{5}{*}{ Age } & Below 30 years & 7 & 32 \\
\hline & $30-39$ years & 7 & 32 \\
\hline & $40-49$ years & 4 & 18 \\
\hline & 50 years and above & 3 & 14 \\
\hline & Not Specified & 1 & 4 \\
\hline \multirow{5}{*}{ Education Level } & Certificate & 1 & 4 \\
\hline & Diploma & 1 & 4 \\
\hline & Undergraduate & 16 & 73 \\
\hline & Post Graduate & 3 & 14 \\
\hline & Not Specified & 1 & 5 \\
\hline \multirow[t]{2}{*}{ Designation } & Head of Department & 21 & 95 \\
\hline & Not Specified & 1 & 5 \\
\hline \multirow[t]{4}{*}{ Company Years of Operation } & 4-7 Years & 2 & 9 \\
\hline & 8-11 Years & 1 & 5 \\
\hline & Over 11 Years & 18 & 81 \\
\hline & Not Specified & 1 & 5 \\
\hline
\end{tabular}
brackets, highest education level, position held in organization, company years of operation.

Table-1: Demographic Data

Source: Research Data, 2020

Table-1 collates the demographic data of the respondents, including the years of operation of the companies considered in this study. Based on the aggregated results, there were more males $(73 \%)$ than females $(23 \%)$. $4 \%$ of the respondents did not specify their gender. The research reveals that most of the individuals at the helm of corporate governance for the firms considered in this study are male. The study finding shows that fewer women are involved in the management of corporate governance.

The demographic data reveals that majority of the respondents were aged below 30 years $(32 \%)$ and $30-39$ years $(32 \%)$. On the other hand, $18 \%$ were $40-49$ years, $14 \%$ were 50 years and above, whereas $4 \%$ of them did not specify their age brackets. The study reveals that most of the persons who handle the docket of corporate governance have an age bracket of below 30 to 39 years. A few are in the age bracket of 50 years and above.

The education level reveals that $73 \%$ of the respondents are undergraduates while $14 \%$ are postgraduates. Moreover, $4 \%$ have certificate and diploma educational levels. $5 \%$ of the respondent did not specify their highest education level. The study reveals that most of the persons who are in charge of corporate governance in the industry under this study have undergraduate education level. A few have diploma and certificate educational level. 
The designation of the respondents shows that $95 \%$ of the respondents are heads of department, whereas $5 \%$ of the respondents did not specify their positions in their respective companies. The study reveals that most of the head of department in the general insurance firms are responsible for the corporate governance of the given organizations. Furthermore, the study establishes that $81 \%$ of the companies have operated for over 11 years, $9 \%$ for 4-7 years, while $5 \%$ of the companies have operated for 8 11 years. $5 \%$ of the companies have not specified their years of operation. The study reveals that most of the general insurance companies in Kenya have operated for over 11 years.

\section{THE RESULTS / FINDINGS}

The findings include all the constructs outlined on the specific objectives of this research work. To test individual hypotheses in this research, regression analysis as a type of inferential statistics was utilized. The combined effect of all the constructs of the explanatory variables on the outcome variable represents the overall effect of governance on corporate performance. It involves consolidated influence of all the constructs of the independent variable, that is, corporate governance, against performance. Audit committee independence, ownership concentration, CEO duality, and the board size constitute the aspects of the governance that affect performance of firms.

Table-2: The Overall Effect of Corporate Governance on Corporate Performance

\begin{tabular}{|c|c|c|c|c|c|c|}
\hline \multicolumn{7}{|c|}{ Model Summary ${ }^{\mathrm{b}}$} \\
\hline \multirow[t]{2}{*}{ Model } & \multirow[t]{2}{*}{$\mathrm{R}$} & \multirow[t]{2}{*}{ R Square } & \multicolumn{4}{|c|}{ Change Statistics } \\
\hline & & & F Change & df1 & $\mathrm{df} 2$ & Sig. F Change \\
\hline 1 & $.123^{\mathrm{a}}$ & .015 & .046 & 1 & 3 & .844 \\
\hline \multicolumn{7}{|c|}{ a. Dependent Variable: Corporate Performance } \\
\hline \multicolumn{7}{|c|}{ b. Predictors: (Constant), Corporate Governance } \\
\hline \multicolumn{7}{|c|}{ Coefficients $^{\mathrm{a}}$} \\
\hline \multirow{2}{*}{\multicolumn{2}{|c|}{ Model }} & Standardized Coefficients & $\mathrm{t}$ & Sig. & \multicolumn{2}{|c|}{ Collinearity Statistics } \\
\hline & & Beta & & & Tolerance & VIF \\
\hline \multirow[t]{2}{*}{1} & (Constant) & & 2.464 & .091 & & \\
\hline & Corporate Governance & .123 & .215 & .844 & 1.000 & 1.000 \\
\hline
\end{tabular}

Source: Research Data, 2020

Table-2 shows the overall effect of corporate governance on corporate performance. The study reveals that corporate governance has no significant effect on corporate performance $(F=0.046$; $p>0.05)$. Corporate governance has a weak correlation $(\mathrm{R}=$ 0.123). $\mathrm{R}^{2}=1.5 \%$ of the variations explained by corporate governance, $98.5 \%$ of the variations are unexplained and are taken care of by the error. Corporate governance has a positive impact on corporate performance $(\beta=0.123)$. The collinearity statistics show that VIF $=1$, meaning that there are no two variable that are correlated and non existence of multicollinearity.
Das [6] suggest that approximating a company's sustainable profitability is a huge challenge to investors. Companies have not been able to boost revenue and return on capital employed simultaneously as they are not also well-matched in comparison with the global capital market. The study is compared to Das [6] whereby the general insurance companies in Kenya are not compatible with the global capital market, since the company's profitability is a big challenge to investors. Therefore, the study is in support of Das [6].

\section{The Effect of Board Size on Corporate Performance}

The first specific objective is to ascertain the effect of board size on corporate performance.

Table-3: The Effect of Board Size on Corporate Performance

\begin{tabular}{|c|c|c|c|c|c|c|}
\hline \multicolumn{7}{|c|}{ Model Summary $^{b}$} \\
\hline \multirow[t]{2}{*}{ Model } & \multirow[t]{2}{*}{$\mathrm{R}$} & \multirow[t]{2}{*}{ R Square } & \multicolumn{4}{|c|}{ Change Statistics } \\
\hline & & & F Change & df1 & df2 & Sig. F Change \\
\hline 1 & $.535^{\mathrm{a}}$ & .286 & 1.200 & 1 & 3 & .353 \\
\hline \multicolumn{7}{|c|}{ a. Dependent Variable: Corporate Performance } \\
\hline \multicolumn{7}{|c|}{ b. Predictors: (Constant), Board size } \\
\hline \multicolumn{7}{|c|}{ Coefficients $^{\mathrm{a}}$} \\
\hline \multirow{2}{*}{\multicolumn{2}{|c|}{ Model }} & Standardized Coefficients & $\mathrm{t}$ & Sig. & \multicolumn{2}{|c|}{ Collinearity Statistics } \\
\hline & & Beta & & & Tolerance & VIF \\
\hline \multirow[t]{2}{*}{1} & (Constant) & & 15.875 & .001 & & \\
\hline & Board size & -.535 & -1.095 & .353 & 1.000 & 1.000 \\
\hline
\end{tabular}

Source: Research Data, 2019 
Table-3 reveals the effect of board size on corporate performance. The study reveals that board size has no significant effect on corporate performance $(\mathrm{F}=1.200 ; \mathrm{p}>0.05)$. Board size has a moderately strong correlation $(\mathrm{R}=0.535) . \mathrm{R}^{2}=28.6 \%$ of the variations explained by board size, $73.4 \%$ of the variations are unexplained and are taken care of by the error. Board size has a negative impact on corporate performance $(\beta=-0.535)$. The collinearity statistics show that $\mathrm{VIF}=1$, meaning that there are no two variable that are correlated and non existence of multicollinearity.
Akpan \& Amran [11] established that performance of firms relates positively and significantly with education and board size. The implication is that the current study is in contrast with that of Akpan \& Amran [11], since the finding of the latter shows that the two variables are negatively related. Therefore, the finding does not in support of Akpan \& Amran [11].

\section{The Effect of CEO Duality on Corporate Performance}

The second objective of our research was to determine the effect of CEO duality on corporate performance.

Table-1: The Effect of CEO Duality on Corporate Performance

\begin{tabular}{|c|c|c|c|c|c|c|}
\hline \multicolumn{7}{|c|}{ Model Summary $^{b}$} \\
\hline \multirow[t]{2}{*}{ Model } & \multirow[t]{2}{*}{$\mathrm{R}$} & \multirow[t]{2}{*}{ R Square } & \multicolumn{4}{|c|}{ Change Statistics } \\
\hline & & & F Change & df1 & df2 & Sig. F Change \\
\hline 1 & $.468^{\mathrm{a}}$ & .219 & .840 & 1 & 3 & .427 \\
\hline \multicolumn{7}{|c|}{ a. Dependent Variable: Corporate Performance } \\
\hline \multicolumn{7}{|c|}{ b. Predictors: (Constant), CEO Duality } \\
\hline \multicolumn{7}{|c|}{ Coefficients $^{\mathrm{a}}$} \\
\hline \multirow{2}{*}{\multicolumn{2}{|c|}{ Model }} & Standardized Coefficients & $\mathrm{t}$ & Sig. & \multicolumn{2}{|c|}{ Collinearity Statistics } \\
\hline & & Beta & & & Tolerance & VIF \\
\hline \multirow[t]{2}{*}{1} & (Constant) & & 7.546 & .005 & & \\
\hline & CEO Duality & .468 & .917 & .427 & 1.000 & 1.000 \\
\hline
\end{tabular}

\section{Source: Resource Data, 2019}

Table-4 shows the effect of CEO Duality on corporate performance. The study reveals that CEO Duality has no significant effect on corporate performance $(\mathrm{F}=0.084 ; \mathrm{p}>0.05)$. CEO Duality has a moderately weak correlation $(\mathrm{R}=0.468) . \mathrm{R}^{2}=21.9 \%$ of the variations explained by CEO Duality, $78.1 \%$ of the variations are unexplained and are taken care of by the error. CEO Duality has a positive impact on corporate performance $(\beta=0.468)$. The collinearity statistics show that VIF $=1$, meaning that there are no two variable that are correlated and non existence of multicollinearity.

Dogan, Elitas, Agca, \& Ogel [8] argue that The CEO duality has a negative impact on the firm performance and is consistent with the agency theory. This study reveals that CEO duality has a positive impact on corporate performnace. These findings are consistent with the key expositions of the agency theory. Nonetheless, the findings from the present study indicate that these two concepts are positively related. Accordingly, these findings from the current study do not support Dogan, Elitas, Agca, \& Ogel [8] argument.

\section{The Effect of Ownership Concentration on Corporate Performance}

Objective three ascertains the effect of ownership concentration on corporate performance.

Table-5: The Effect of Ownership Concentration on Corporate Performance

\begin{tabular}{|c|c|c|c|c|c|c|c|}
\hline \multicolumn{8}{|c|}{ Model Summary ${ }^{b}$} \\
\hline \multirow[t]{2}{*}{ Model } & \multirow[t]{2}{*}{$\mathrm{R}$} & \multirow[t]{2}{*}{ R Square } & \multicolumn{5}{|c|}{ Change Statistics } \\
\hline & & & \multicolumn{2}{|c|}{ F Change } & df1 & df2 & Sig. F Change \\
\hline 1 & $.214^{\mathrm{a}}$ & .046 & \multicolumn{2}{|l|}{.143} & 1 & 3 & .730 \\
\hline \multicolumn{8}{|c|}{ a. Dependent Variable: Corporate Performance } \\
\hline \multicolumn{8}{|c|}{ b. Predictors: (Constant), Ownership Concentration } \\
\hline \multicolumn{8}{|c|}{ Coefficients $^{\mathbf{a}}$} \\
\hline \multirow{2}{*}{\multicolumn{2}{|c|}{ Model }} & Standardized Coefficients & \multirow[t]{2}{*}{$\mathrm{t}$} & \multirow[t]{2}{*}{ Sig. } & \multicolumn{3}{|c|}{ Collinearity Statistics } \\
\hline & & Beta & & & To & & VIF \\
\hline \multirow[t]{2}{*}{1} & (Constant) & & 20.330 & .000 & & & \\
\hline & Ownership Concentration & .214 & .379 & .730 & 1.0 & & 1.000 \\
\hline
\end{tabular}

Source: Research Data, 2020 
Table-5 shows the effect of ownership concentration on corporate performance. The study reveals that ownership concentration has no significant effect on corporate performance $(\mathrm{F}=0.143$; $\mathrm{p}>0.05)$. Ownership concentration has a weak correlation $(\mathrm{R}=$ 0.214). $\mathrm{R}^{2}=4.6 \%$ of the variations explained by ownership concentration, $95.4 \%$ of the variations are unexplained and are taken care of by the error. Ownership concentration has a positive impact on corporate performance $(\beta=0.214)$. The collinearity statistics show that VIF $=1$, meaning that there are no two variable that are correlated and non existence of multicollinearity.

Table-6: The Effect of Audit Committee Independence on Corporate Performance

\begin{tabular}{|c|c|c|c|c|c|c|}
\hline \multicolumn{7}{|c|}{ Model Summary $^{b}$} \\
\hline \multirow[t]{2}{*}{ Model } & \multirow[t]{2}{*}{$\mathrm{R}$} & \multirow[t]{2}{*}{ R Square } & \multicolumn{4}{|c|}{ Change Statistics } \\
\hline & & & F Change & df1 & df2 & Sig. F Change \\
\hline 1 & $.408^{\mathrm{a}}$ & .167 & .600 & 1 & 3 & .495 \\
\hline \multicolumn{7}{|c|}{ ANOVA $^{\mathrm{a}}$} \\
\hline \multicolumn{7}{|c|}{ a. Dependent Variable: Corporate Performance } \\
\hline \multicolumn{7}{|c|}{ b. Predictors: (Constant), Audit Committee Independence } \\
\hline \multicolumn{7}{|c|}{ Coefficients $^{\mathrm{a}}$} \\
\hline \multirow{2}{*}{\multicolumn{2}{|c|}{ Model }} & Standardized Coefficients & $\mathrm{t}$ & Sig. & \multicolumn{2}{|c|}{ Collinearity Statistics } \\
\hline & & Beta & & & Tolerance & VIF \\
\hline \multirow[t]{2}{*}{1} & (Constant) & & 15.195 & .001 & & \\
\hline & $\begin{array}{l}\text { Audit Committee } \\
\text { Independence }\end{array}$ & -.408 & -.775 & .495 & 1.000 & 1.000 \\
\hline
\end{tabular}

Source: Research Data, 2020

Table- 6 shows the effect of audit committee independence on corporate performance. The study reveals that audit committee independence has no significant effect on corporate performance $(F=0.600$; $\mathrm{p}>0.05)$. Audit committee independence has a moderately weak correlation $(\mathrm{R}=0.408) . \mathrm{R}^{2}=16.7 \%$ of the variations explained by audit committee independence, $83.3 \%$ of the variations are unexplained and are taken care of by the error. Audit committee independence has a negative impact on corporate performance $(\beta=-0.408)$. The collinearity statistics show that VIF $=1$, meaning that there are no two
Kalezic [9] suggests that performance of firms could have either negative or positive relationship with ownership concentration. The study supports Kalezic [9] suggestion.

\section{The Effect of Audit Committee Independence on the Corporate Performance}

Objective four of the study endeavored to determine the effect of the independence of the audit committee on corporate performance. variable that are correlated and non existence of
multicollinearity

This result partially agrees with a study conducted by Zraiq and Bt Fatzil [20] who contended that there is no statistical significance between performance and independence of the audit committee.

\section{Corporate Performance}

The corporate performance measurement involve return on capital employed (ROCE), , return on equity (ROE) and return on assets (ROA).

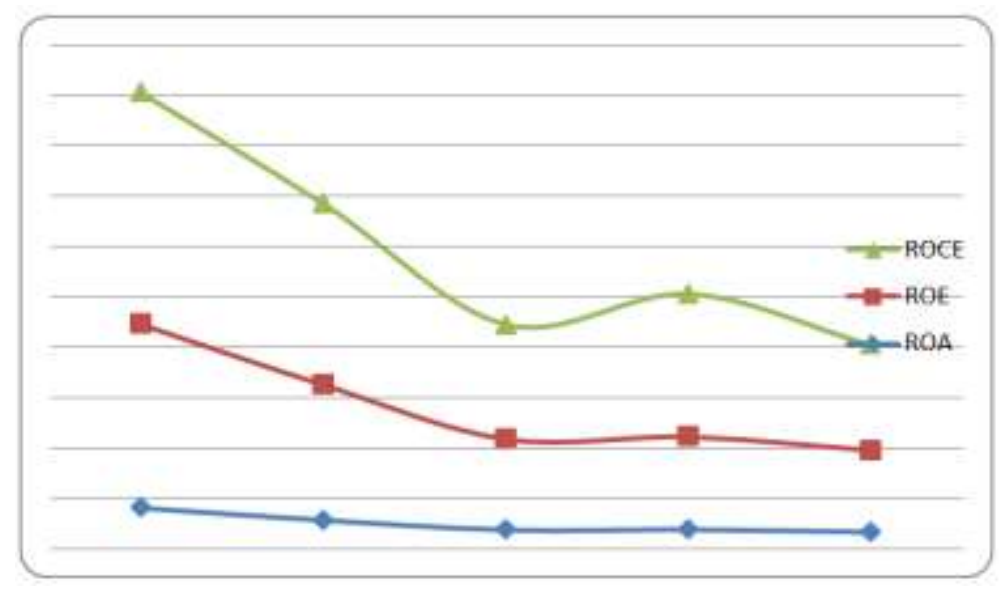

Fig-1: Corporate Performance

Source: Association of Kenya Insurers (2018) 
Figure-1 reveals that the indicators of corporate governance which include ROCE, ROE, and ROA had gradual decrease between 2013 and 2015 . However, the aforesaid indicators slightly increased in 2016 and further decreased in 2017.

\section{DISCUSSION OF THE FINDINGS}

Based on analysis of collected data, the researchers established that corporate performance is not significantly influenced by corporate governance. To provide a holistic approach to delineating the impact of governance on performance, the study analyzed the effect of CEO duality, ownership concentration, board size, and audit committee independence on corporate performance. The subsequent sections summarize each of the specific objectives.

Analysis of the effect of board size on corporate performance, established that the size of an organization's board does not significantly affect performance. Conversely, the correlation depicted between governance and a board's size is moderately strong and takes the negative direction. This finding does not resonate well with empirical studies. For instance, this result on negative relationship differs with a study conducted by Akpan \& Amran [11] who suggested that corporate performance and board size exhibit a positively significant connection, suggesting that the board's size ultimately affect peformance of a company.

Analysis of the effect of CEO Duality on corporate performance, establishes that corporate performance has no effect by CEO Duality. In addition, Pearson's coefficients of determination reveal that CEO Duality portrays a positive weak association with performance. Relating this finding to other existing scholarly literature on the concept of corporate performance, it is evident that the current study's results are incongruent with those established by a study done by Dogan, Elitas, Agca, and Ogel (2013) who stated that corporate performance and CEO duality are negatively correlated.

Analysis of the effect of ownership concentration on corporate performance reveals that ownership concentration in insurance companies has no effect on corporate performance. Furthermore, Pearson's coefficients of determination reveal that ownership concentration of general insurance companies depicts a positive, but weak correlation with performance. The finding partially agrees with existing literature, where scholars, such as Kalezic [9], who argued that corporate performance and concentration of corporate ownership relate positively.

Analysis of the effect of audit committee independence on corporate performance, established that audit committee independence has no statistical significant effect on corporate performance. Besides,
Pearson's coefficients of determination reveal that performance and independence of the audit committee show a weak and negative correlation. The result partially agrees with a study conducted by Zraiq and Bt Fatzil [20] who contended that independence of audit committee portrays no statistically signficant linkage to corporate performance.

\section{CONCLUSION}

Based on the research objectives, this study concludes that performance of general insurance companies is not predicted by corporate governance. This result seems to suggest that approaches employed by companies in their day-to-day management processes and practices do not influence corporate performance. Moreover, this research work concludes that all the board size, CEO duality, ownership concentration and audit committee independence do not significantly affect corporate performance. The outcome of this research endeavor provides essential insights into policy formulation and contribution to theoretical development. Theoretically, the findings will add to the advancement of the stakeholder theory and agency theory. This suggests that the findings of the current study link corporate performance and corporate governance, which means that constructs derived from corporate governance theories, can be used to explain corporate performance.

This research work established that dimensions of corporate governance adopted in this study do not influence performance of general insurance companies. Accordingly, it is recommended that apt corporate governance policies should be applied in a manner that reflect the vision and mission of a company with a view to make certain effective and efficient corporate performance. This suggests that suitable corporate governance policies enhance the capability of insurance companies to realize competitive advantage. Thus, this study underscores the essentials of corroborating the results on all the dimensions of corporate governance on corporate performance.

\section{RECOMMENDATION}

The research recommends that scholars, researchers, and academicians can use results obtained in this study since the implications of the findings offer critical entry points in the study of performance of organizations, particularly within the spectrum of insurance firms. The study appreciates that there were areas not covered in the present paper, signifying that further research should be sanctioned in other sectors and/or industries to establish the relationship performance and governance. In doing so, outcomes of the study can be easily be compared with a view to establishing whether they will be congruent or incongruent. 


\section{REFERENCES}

1. Palanissamy A. CEO Duality - An Explorative Study. European Scientific Journal, Special Edition 1, 2015; 33-44.

2. Kyereboah-Coleman A, Biekpe N. The Relationship Between Board Size, Boardcomposition, CEO duality and firm performance: Experience From Ghana. Researchgate, 2014;1-19.

3. Insurance Regulatory Authority. Insurance Industry Annual Report. Nairobi: Insurance Regulatory Authority. 2017.

4. Rosika, Prananingrum, DK, Muthalib DA, Azis MI, Rohansyah M. Effects of Return on Asset, Return on Equity, Earnings per Share and Corporate Value. The International Journal of Enginnering and Science, 2018; 7(3), 6-14.

5. Heikal M, Khaddafi M, Ummah A. Influence Analysis of Return on Assets (ROA), Return on Equity (ROE), Net Profit Margin (NPM), Debt to Equity Ratio (DER), and Current Ratio (CR), Against Corporate Profit Growth In Automotive In Indonesia Stock Exchange. International Journal of Academic Research in Business and Social Sciences, 2014; 4(12), 101-114.

6. Das PK. Impact on Capital Employed on Company Performance - An Introspection in India. The Journal of Business and Management Studies, 2017; 848-853.

7. Panda B, Leepsa NM. Agency Theory: Review of Theory and Evidence on Problems and Perspectives. Indian Journal of Corporate Governance, 2017; 10(1), 74-95.

8. Dogan M, Elitas BL, Agca V, Ogel S. The Impact of CEO Duality on Firm Performance: Evidence From Turkey. International Journal of Business and Social Science, 2013; 4(2), 149-155.

9. Kalezic Z. Ownership Concentration and Firm Performance in Transition Economies: Evidence from Montenegro. Journal of Central Banking Theory and Practice, 2015; 5-64.

10. Association of Kenya Insurers. AKI Industry Annual Report. Nairobi: Association of Kenya Insurers. 2018.

11. Akpan EO, Amran NA. Board Characteristics and Company Performance: Evidence From Nigeria. Journal of Fince and Accounting, 2014; 2(3),81-89.

12. Ning Y, Davidson WN, Wang J. Does optimal corporate board size exist? An empirical analysis. Journal of Applied Finance (Formerly Financial Practice and Education). 2010 Nov 19;20(2).

13. Ghosh A, Moon D. When the CEO is also the Chair of the Board. New York: Zicklin School of Business. 2009.
14. Vintila G, Gherghina SC. The Impact of Ownership Concentration on Firm Value. Empirical Study of the Bucharest Stock Exchange Listed Companies. Procedia Economics and Finance, 2014; 15, 271279.

15. Ma S, Naughton T. Ownershiip and Ownership Concentration: Which Is Important in Determining the Performance of China's Listed Firms? Accounting and Finance, 2010; 50(4), 871-897.

16. Daoud KA, Al-Sraheen DAD, Aleqab MM. Does CEO Duality and Family Ownership Concentration Hinder the Effectiveness of the Corporate Board of Directors in Jordanian Service Firms. Journal of Environmental Accounting and Management, 2018; 6(2), 95-104.

17. Permwanichagun $\mathrm{P}$, Kaenmanee S, Naipinit A, Na Sakolnakorn TP. The situation of Sole Proprietorship, E-Commerce Entrepreneurs and Trends in their E- Commerce: A Case Study in Thailand. Asian Social Science, 2014; 10(21), 8088.

18. Bansal N, Sharma AK. Audit Committee, Corporate Governance and Firm Performance: Empirical Evidence from India. International Journal of Economics and Finance, 2016; 8(3), 103-116.

19. Sean CS, Chyi CS, Choo KT, Yi LX, Hong PZ. Audit Committee Characteristics and Firm Performance of Public Listed Companies in Malaysia. Bursa: Universiti Tunku Abdul Rahman. 2016.

20. Zraiq MA, Bt Fatzil FH. The Impact of Audit Committee Characteristics on Firm Performance: Evidence from Jordan. Scholar Journal of Applied Sciences and Research, 2018; 1(5), 39-42.

21. ICPAK. The Effectiveness of Audit Committees In The Public Sector. Institute of Certified Public Accountants of Kenya (pp. 1-20). Sarova Whitestands Hotel, Mombasa: ICPAK. 2016.

22. Mwangi AK. Effect of Audit Committee Characteristics on Quality of Financial Reporting Among Non-commercial State Corporations In kenya. Nairobi: Jomo Kenyatta University of Agriculture and Technology. 2018.

23. Akhtar MI. Research Design. Research in Social Science Interdisciplinary Perspectives, 2016; 6884.

24. Mugenda OM, Mugenda AG. Research Methods: Quantitative and Qualitative Approaches (1st ed.). Kenya: African Centre for Technology Studies. 2003.

25. Cooper D, Schindler PS. Business Research methods (9th ed.). New York: McGraw Hill Companies Inc. 2006. 